\section{Soviet nuclear dissent}

Chernobyl is not the only reason why Soviet civil nuclear power is behind target. Can it pull back?

With the possible exception of the government of France, the Soviet government has so far been among the most resolute (and successful) in the pursuit of civil nuclear power. It is natural that the accident at Chernobyl should have given the nuclear planners pause, but that is not the only reason why $28 \mathrm{GW}$ of planned capacity has been stripped from the original plans during the past year (see page 298). Even before the appointment of Mr Mikhail Gorbachev as Party general-secretary, there had been protests in republics as different as those in the south and the north-west at plans to build nuclear power stations there, often apparently as if to canalize more general discontent in directions that could not be held to be illegitimate. The coming of glasnost has inevitably complicated the planners' lives, creating for Soviet agencies problems to which they are unused - those of winning advance public approval for projects that, in the old days, would have been decided on strictly administrative grounds.

Now they are in a real fix. Members of the Soviet public have been given both a foundation (the Chernobyl accident, and the hair-raising evidence of mismanagement that it revealed) and a mechanism (glasnost, which is not merely a licence for the press, but for local and regional Soviets as well) for dissent. The result is that opposition to the nuclear power programme is no longer simply confined to what are called intellectuals, or to republic nationalists (the Lithuanian government last year declined to contribute, as required, towards the cost of a fourth reactor being built at a site on its territory), but is much more broadly based. Moreover, local and regional Soviets, whose consent is formally required for developments in their spheres of influence, can now speak up and have an incentive to do so. (Selfinterest will have their members calculating that unpopularity with constituents may lead to defeat in some future popular election, if the electoral system does indeed develop along democratic lines.) Worse still, the nuclear planners find that the Soviet press has emerged into glasnost with a distinctly antinuclear predilection, born partly of Chernobyl and partly of the appearance of complacency among the managers. The result is that an article by somebody in high authority in a sufficiently august newspaper will no longer suffice to turn public opinion around. Nuclear planners in the West would find themselves on familiar ground in the Soviet Union now.

What is to be done? The Soviet target of $100 \mathrm{GW}$ of nuclear generating capacity by the year 2010 looks unattainable. There are optimists who believe that $80 \mathrm{GW}$ might be managed, but even that target must depend crucially on what happens in the next few years. Yet on traditional planning assumptions, nuclear generating capacity on some such scale will be needed if intended industrial developments are to succeed. Moreover, most of this extra power will be needed in the western regions of the Soviet Union, which happen also to be where most people live, and are now able to dissent. The assumptions on which the planners' forecasts are based may, of course, be incorrect, but in the absence of market pricing for different kinds of fuel, there is no way of being sure. Similarly, in the absence of direct incentives for users (as distinct from planners) to economize in the use of energy, the Soviet Union cannot easily expect that fuel efficiency will take the edge off the growth of electricity demand, as it has done in the West since 1973.

So there is no choice but to win round public opinion - a daunting task requiring that the Soviet nuclear industry should be even more adventurous in its exploitation of glasnost than even the most adventurous of the Moscow newspapers. Experience elsewhere (Britain, for example) shows that people must be told of routine mishaps at nuclear plants (as in industrial enterprises of all kinds) in the hope that they may eventually become familiar with the notion that the nuclear industry does not need to be literally free from accidents (but it has to be something of a paragon) to be safely manageable. It will be interesting, and may be instructive for the West, to see how brave the Soviet planners will be in these unfamiliar circumstances. But that they have little choice is beyond dispute. Meanwhile, in the search for nuclear generation sites, there seems little choice but to build new reactors at existing sites until the winds of dissent have abated.

\section{US budget pragmatism}

\section{The US budget problem is not its size, but how to}

cut it.

Senator Lloyd Benson's celebrated gibe at now-Vice-President Daniel Quayle, "You're no Jack Kennedy", might as well have been levelled at President George Bush last Friday, after his low-key inaugural address. But Bush is none the worse for that. Not every US president needs to sound like a Lincoln, a Roosevelt or a Kennedy, nor is rhetoric at the beginning of a four- or eight-year stint a guide to performance in the future. It may even help in present circumstances if the new presidency is seen to be manned by down-to-earthers who prefer to deal with real problems by solving them.

As yet, unfortunately, there are only straws in the wind as guides, and they seem to be blowing in contradictory directions. Everybody appreciates that US government support for research, like all its other discretionary expenditures, will be determined by the outcome of this year's tussle over the budget. As always, nobody will forget that this year's new congressmen (there are not many) will be campaigning for re-election before the next financial year (called fiscal 1990) is up. The best hope is that revenues can be modestly increased (preferably by natural growth, otherwise by devices that cannot this year be called taxes) and that expenditure can be selectively reduced. There are some signs of grace. The new National Security Adviser, the formidably phlegmatic General Brent Scowcroft, may have been less than enthusiastic about the Strategic Defense Initiative on television at the weekend: does that mean that a large part of $\$ 5,600$ million, three times the budget of the National Science Foundation, has been saved already?

On the other side of the coin, there is a general air about the new administration suggesting scepticism of President Ronald Reagan's commitments to the arms control processes begun in the past six years. It is true, of course, that the new president is much less sceptical than was Reagan on entering office, and that it is natural that a new administration should turn a quizzical eye on the deals its predecessors have been making with others, if only to be sure of understanding them. It would not be the end of the world if the Bush administration should conclude, for example, that it would prefer to abandon the proposed 50 per cent reduction of strategic arms in favour of some other accommodation with the Soviet Union and its allies in the Warsaw pact.

Yet those in Washington now musing aloud that $\mathrm{Mr}$ Gorbachev is interested in arms control and other accommodations only because of his domestic economic problems (and Gorbachev appears to admit that his budget is part of his motive) should reflect that the same calculation could apply to the United States. The most inflexible part of the US budget is that (nearly a third) spent by the Pentagon. The years immediately ahead will be especially difficult because development projects will be clamouring for procurement. Would it not be a prize worth having to be able to cut the defence budget without endangering security? The new administration is only a few days old, and there are many urgent matters clamouring for attention, but it will be a misfortune of this trade-off has not arisen naturally before the budget negotiations reach their climax later in the year. 